\title{
Site selection by geese in a suburban landscape
}

\author{
Quentin J Groom $^{\text {Corresp., } 1 \text {, Tim Adriaens }}{ }^{2}$, Claire Colsoulle ${ }^{3}$, Pauline Delhez ${ }^{4}$, Iris Van der Beeten ${ }^{1}$ \\ 1 Meise Botanic Garden, Meise, Vlaams Brabant, Belgium \\ 2 Research Institute for Nature and Forest (INBO), Brussels, Belgium \\ 3 Université catholique de Louvain, Louvain-la-Neuve, Belgium \\ 4 Université de Liège, Liège, Belgium \\ Corresponding Author: Quentin J Groom \\ Email address: quentin.groom@plantentuinmeise.be
}

\section{Background}

In European and North American cities geese are among the most common and most visible large herbivores. As such, their presence and behaviour often conflict with the desires of the human residents. Fouling, noise, aggression and health concerns are all cited as reasons that there are "too many". Lethal control is often used for population management, however, this raises questions about whether this is a sustainable strategy to resolve the conflict between humans and geese, when paradoxically, it is humans that are responsible for creating the habitat and often providing the food and protection of geese at other times. We hypothesise that the landscaping of suburban parks can be improved to decrease its attractiveness to geese and to reduce the opportunity for conflict between geese and humans.

Methods

Using observations collected over five years from a botanic garden situated in suburban Belgium and data from the whole of Flanders in Belgium, we examined landscape features that attract geese. These included the presence of islands in lakes, the distance from water, barriers to level flight and the size of exploited areas. The birds studied were the tadornine goose Alopochen aegyptiaca (L. 1766) (Egyptian goose) and the anserine geese, Branta canadensis (L. 1758) (Canada goose), Anser anser (L. 1758) (greylag goose) and Branta leucopsis (Bechstein, 1803) (barnacle goose). Landscape modification is a known method for altering goose behaviour, but there is little information on the power of such methods with which to inform managers and planners.

Results

Our results demonstrate that lakes with islands attract more than twice as many anserine geese than lakes without islands, but make little difference to Egyptian geese. Furthermore, flight barriers between grazing areas and lakes are an effective deterrent to geese using an area for feeding. Keeping grazing areas small and surrounded by trees reduces their attractiveness to geese.

Conclusion

The results suggest that landscape design can be used successfully to reduce the number of geese and their conflict with humans. However, this approach has its limitations and would require humans to compromise on what they expect from their landscaped parks, such as open vistas, lakes, islands and 


\section{Site Selection by Geese in a Suburban Landscape}

2 Quentin John Groom ${ }^{1}$, Tim Adriaens ${ }^{2}$, Claire Colsoulle ${ }^{3}$, Pauline Delhez ${ }^{4}$, Iris Van Der Beeten ${ }^{1}$

3 1. Meise Botanic Garden, Nieuwelaan 38, 1860 Meise, Belgium

4 2. Research Institute for Nature \& Forest (INBO), Havenlaan 88 bus 73, B-1000 Brussels,

$5 \quad$ Belgium

6 3. Université catholique de Louvain, B-1348 Louvain-la-Neuve, Belgium

7 4. University of Liège, 4000 Liège, Belgium

8 Corresponding Author:

9 Quentin Groom 
12

13

14

15

16

17

18

19

20

21

22

23

24

25

26

27

28

29

30

31

32

33

34

35

36

37

38

39

40

41

42

43

44

45

46

47

48

49

51

50 Egyptian geese, Alopochen aegyptiaca, Canada geese, Branta canadensis, greylag geese, Anser

\section{ABSTRACT}

\section{Background}

In European and North American cities geese are among the most common and most visible large herbivores. As such, their presence and behaviour often conflict with the desires of the human residents. Fouling, noise, aggression and health concerns are all cited as reasons that there are "too many". Lethal control is often used for population management, however, this raises questions about whether this is a sustainable strategy to resolve the conflict between humans and geese, when paradoxically, it is humans that are responsible for creating the habitat and often providing the food and protection of geese at other times. We hypothesise that the landscaping of suburban parks can be improved to decrease its attractiveness to geese and to reduce the opportunity for conflict between geese and humans.

Methods

Using observations collected over five years from a botanic garden situated in suburban Belgium and data from the whole of Flanders in Belgium, we examined landscape features that attract geese. These included the presence of islands in lakes, the distance from water, barriers to level flight and the size of exploited areas. The birds studied were the tadornine goose Alopochen aegyptiaca (L. 1766) (Egyptian goose) and the anserine geese, Branta canadensis (L. 1758) (Canada goose), Anser anser (L. 1758) (greylag goose) and Branta leucopsis (Bechstein, 1803) (barnacle goose). Landscape modification is a known method for altering goose behaviour, but there is little information on the power of such methods with which to inform managers and planners.

Results

Our results demonstrate that lakes with islands attract more than twice as many anserine geese than lakes without islands, but make little difference to Egyptian geese. Furthermore, flight barriers between grazing areas and lakes are an effective deterrent to geese using an area for feeding. Keeping grazing areas small and surrounded by trees reduces their attractiveness to geese.

\section{Conclusion}

The results suggest that landscape design can be used successfully to reduce the number of geese and their conflict with humans. However, this approach has its limitations and would require humans to compromise on what they expect from their landscaped parks, such as open vistas, lakes, islands and closely cropped lawns.

\section{Keywords}

1 anser, barnacle geese, Branta leucopsis, feral, invasive, Flanders, Belgium, behaviour, habitat, 
52 suburban

\section{Introduction}

54 In Europe and North America wild and feral geese frequently inhabit artificial lakes and their

55 surrounding parks in urban and suburban areas. These parks are appreciated by people for their

56 recreational and aesthetic value. However, this often brings geese in conflict with people

57 (Conover \& Chasko, 1985; Hughes et al., 1999; Smith, Craven \& Curtis, 1999; Fox, 2019). While

58 people often enjoy seeing small numbers of geese, when there are large flocks the soil becomes

59 fouled and people are intimidated by the geese's threatening behaviour (Miller et al., 2001).

60 Geese are also known to exert pressure on small water bodies such as ponds, reducing water

61 quality through eutrophication (Allan et al., 1995; Gosser et al., 1997; Smith et al., 2000;

62 Kumschick \& Nentwig 2010). They have also been suggested to be a disease risk, though the

63 evidence is circumstantial and other domestic and wild animals pose a greater known risk

64 (Fleming \& Fraser, 2001; Clark, 2003; Bönner et al. 2004). Throughout Europe and the western

65 Palearctic, native as well as non-native geese are increasing in numbers and distribution (Allan,

66 Kirby \& Feare, 1995; Fox et al. 2010). Several populations have developed a resident

67 component and their year-round presence increases human-wildlife conflicts and impacts on

68 biodiversity (Buij et al. 2017). A variety of strategies are needed to reduce these impacts (Austin

69 et al., 2007; Gyimesi \& Lensink, 2012).

70

71 In Europe, from the $18^{\text {th }}$ century onwards, it has been traditional to create landscaped parks

72 reflecting an idealised vision of the countryside. Lakes with islands, open vistas, lawns and 
73 patches of woodland are typical (Turner, 1985). Lake-side vegetation and lawns are cut

74 regularly and the canopies of trees are kept high to ensure unimpeded views. For those goose

75 species that are habituated to the presence of people, such landscapes are very suitable, they

76 have abundant grazing; proximity to water and islands for undisturbed nesting sites. In

77 addition, people often provide supplementary feeding.

78

79 In north-western Europe four species of "geese" are the main inhabitants of urban and suburban parks, non-native Egyptian geese (Alopochen aegyptiaca), Canada geese (Branta canadensis), mixed populations of wild and feral greylag geese (Anser anser) and barnacle geese (Branta leucopsis)(Fox et al. 2010). All are members of the family Anatidae, but Egyptian geese are members of the subfamily Tadorninae, which are referred to as tadornine geese,

84 whereas the others are members of subfamily Anserinae, which are referred to as anserine geese (Livezey 1996). Egyptian geese are similar in several aspects to anserine geese, such as their large size, long neck and feeding behaviour, but they do differ in other important aspects.

87 Anserine geese, such as Canada geese, barnacle geese, greylag geese and their hybrids, usually nest on the ground close to bodies of water and are also likely to form large flocks (Adriaens et al. 2020). Egyptian geese are also water birds, but their biology shows many characteristics of a duck, including larger clutch sizes. Although they nest on the ground, their nest site selection is highly variable and they also nest in large tree holes, on buildings, on top of willow trees or in nest boxes (Gyimesi \& Lensink 2012; Huysentruyt et al. 2020). They also differ in their social behaviour. Paired Egyptian geese defend territories near their nest site before and during

94 nesting. Large flocks of Egyptian geese only occur after breeding during moulting (Gyimesi \& 
95

96

97 The site selection criteria of geese are important, because their sites can bring them into

104

105

106

107

108

109

110

111

112

113

114

115

116

Lensink 2010).

conflict with people. The proximity of water, food and breeding sites are relevant to goose site selection, but there are likely to be additional influences. These habitat features may be related to predator avoidance (Conover \& Kania, 1991), accessibility of feeding grounds for adults and families with chicks, nutritional quality of feed (Owen, Nugent \& Davies, 1977; Fox \& Kahlert, 2005), sward length (Hassall, Riddington \& Helden, 2001; Feige et al., 2008; Conover, 1991; Van Gils et al., 2009; Huysentruyt \& Casaer, 2010) and competition with other grazers such as other geese, livestock and rabbits (Van der Wal, Kunst \& Drent, 1998). Given this, it may be possible to identify management strategies and landscape features that alter the site selection of geese and these might be used to control the geese in such a way to reduce conflict between geese and people (Conover, 1992; Owen, 1975).

Culling is often used to reduce the impact of geese (Reyns et al. 2018), but several other strategies have been used to discourage and redistribute geese, including birds scarers and chemical antifeedants (Conover, 1985), fencing of feeding grounds or landscape modification, including altered mowing regimes or landscaping solutions (Cooper 1998; Van Daele et al. 2012). In the context of a landscaped park with large numbers of visitors, culling risks losing public support for a public garden and bird scaring might disturb people too. At the same time, a botanic garden needs to consider the impact of grazing and fouling on plantings, lawns and vegetation, without losing the recreational opportunities for wildlife watching provided by the 
117 presence of these attractive birds. Therefore, habitat modification is considered as a cost

118 effective, sustainable solution to reduce numbers of geese on sites and to mitigate the impact

119 (Conover, 1992). Previous studies on site occupancy of geese have concentrated on wild geese

120 in more or less rural settings. These studies have concentrated on ways to discourage geese

121 from feeding on crop plants (e.g. Olsson et al., 2017; Si et al., 2011). In the case of Canada geese

122 most studies have occurred in North America (e.g. Conover, 1992).

123

124 The aim of this study is to quantify the site selection of the different species of geese within

125 Meise Botanic Garden (Belgium) and create models to predict their behaviour based upon the

126 landscape of the Garden. These models can then be used to suggest strategies to reduce

127 conflict between the geese and the visitors to the Garden without losing the opportunities they 128 represent for wildlife watching.

130 Materials \& Methods

131 Most of the research was conducted at Meise Botanic Garden (Flanders, Belgium), situated just

132 north of Brussels, Belgium (5055'42.4"N $\left.4^{\circ} 19^{\prime} 37.6^{\prime \prime} \mathrm{E}\right)$. The exception was the study on the

133 effect of islands and those data are described below. The 92 ha Garden is a landscaped park like

134 many such parks in northern and western Europe. It has extensive lawns, woodlands, two large

135 lakes and one small one (Fig. 1). The Garden is subdivided into different numbered areas,

136 divided by paths, which join various historic buildings and greenhouses with formal gardens,

137 with approximately half the area covered by woodland. Most of the grassland is mown 
138 between two and four times a month during the growing season, though small areas are

139 maintained as wildflower meadows and are cut once or twice a year. All geese in the Garden

140 are considered either non-native or feral. All species breed in the Garden, though the breeding

141 of Canada geese is, in part, controlled by egg-shaking. The birds using the Garden are part of a

142 larger population of geese that inhabit the greater Brussels area, and birds move in and out of

143 the Garden to the many other lakes and waterways in the neighbourhood. None of these

144 populations are truly migratory, except for local movements (Anselin \& Cooleman, 2007).

145 Canada goose is under management in the region and flocks of geese are regularly moult

146 captured on water bodies in neighbouring municipalities since 2010 (Reyns et al. 2018). The

147 Garden is in almost constant use by geese except for on the rare occasions when the lakes

148 freeze over for long periods in the winter. Geese feed on all the lawns and grasslands within the

149 Garden, but the extent to which these areas are used varies considerably from area to area and 150 from species to species.

\section{The preference for grazing areas}

152 The usage by geese of the different areas of the Botanic Garden was assessed by fixed transect

153 counts (Groom, 2019a; Groom, 2019b). A total of four routes around the Garden were used,

154 each route took approximately 40 minutes to walk and was always walked in a clockwise

155 direction. Almost all of the grassland areas of the Garden were counted on at least two of these

156 routes, woodland sectors were only counted when they were on the route between grassland

157 areas.

158 Transect counts were conducted between $12 \mathrm{pm}$ and $2 \mathrm{pm}$ Central European Time. Geese were 
159

160

161

162

163

164

165

166

167

168

169

170

171

172

173

174

175

176

177

178

179

180

counted on an average of 2.7 days per week spread throughout the survey period that lasted

nearly 6 years, between 11 Oct 2011 and 10 July 2017. Counts were conducted only on Monday

to Friday at the convenience of the surveyors, but irrespective of weather conditions. The only

consistent period of the year when surveying was not conducted was between 25th December

and 1st January. On a few occasions, two routes were walked simultaneously to give an

approximate number for the total number of geese in the Garden for that day. Routes 1 and 2

gave the best coverage for all the main areas used by geese in the Garden. On other days

routes 1 to 4 were chosen at random (Haahr 2019). All the observation data are available on

the Global Biodiversity Information Facility (Groom, 2019c).

It has been well argued, with good justification, that detectability is an important consideration

in site occupancy modelling of animals (Kéry \& Schmidt, 2008). Nevertheless, geese are large,

noisy and bold and easy to recognize apart from the occasional hybrid. The areas where they

feed in the Garden are small and open. Therefore, counts of the geese are expected to be

reliable. We have not considered detectability in our analysis as we have no reason to think

that this would make a difference to the results.

In one year, four hybrids were observed, two between greylag and Canada geese and two

between barnacle and Canada geese. Furthermore, many of the greylag geese were either

escapes from captivity or hybrids with farmed birds. Nevertheless, such distinctions were not

made during counting and hybrids were counted along with the species they consorted with.

Three landscape parameters were examined for their importance for geese in site selection: the size of the survey area, the distance from the site to the nearest lake and the presence of physical barriers preventing direct flight to the nearest lake. Details of each survey sector are 
181 available in Groom (2019b). For the physical barriers, each area was evaluated as to whether it

182 was surrounded by barriers, such as tall trees and buildings that prevented easy flight access

183 either to or from the lakes to the sector (Fig. 1).

184 These data have several issues which need to be addressed in statistical models/ These are

185 seasonal variations in behaviour, temporal autocorrelation and potentially spatial

186 autocorrelation. Various statistical modelling approaches were considered including

187 generalized linear models, mixed effects models and time series models. However, although

188 these techniques might be useful to extract other valuable information from these data, we

189 determined that, for the questions we wanted to answer, we would fit linear models to the

190 mean individual count per sector. By averaging site occupancy across time, we eliminate the

191 issue of temporal autocorrelation. Model selection was achieved by stepwise simplification of

192 the model as described in Crawley (2012), using the step and Im functions of R (Venables \&

193 Ripley, 2002). Independent variables were the area of the sector; the closest distance from the

194 sector to the nearest lake; whether the sector was woodland (1) or grassland (0) and the

195 presence or absence of flight barriers out of the sector towards the lakes. The log of the mean

196 individual count per sector was our dependent variable. Evaluation of our initial models using

197 residuals versus leverage plots showed that the sectors containing lakes $(13,18 \& 21)$ had a

198 disproportionate influence on the models as judged by the Cook's Distance. This is not

199 surprising as the behaviour of geese and their relation to these areas is very different to

200 grassland areas they visit to graze. For this reason, the lake sectors of the Garden were

201 excluded from our models. This reduced the number of sectors used for the model to 29, but

202 no sector had a disproportionate influence on the models. Residuals verses fitted Q-Q plots 
203 were used to test whether residuals were normally distributed. A scale-location plot was used

204 to test for homoscedasticity, meaning that the variance of the residual is homogenous across

205 the range of the model. R version 3.4.1 was used in all modelling and data manipulations.

\section{Edge effects between grassland and woodland}

207 Where goose grazing lawns are bordered by woodland it is reasonable to expect an edge effect,

208 whereby the difference in usage by geese at a woodland-lawn boundary is gradual rather than

209 abrupt. These might be the result of decreased forage quality in the partial shade of trees, or

210 perhaps the avoidance of areas that give cover to potential predators. The use by geese of

211 different areas of lawn was estimated by the amount of droppings on the lawn. Geese defecate

212 frequently and seemingly indiscriminately. Counting dropping is a well-known method for

213 estimating relative intensity of goose grazing on areas of land (Owen, 1971; Van Gils et al.

214 2010). However, we found it difficult to distinguish individual defecation events, because the

215 droppings tend to break apart as they are released. Therefore, we preferred to measure the

216 total length of droppings in a unit area. We considered this measure more reliable than trying

217 to count the number of defecation events.

218 The presence of edge effects was investigated with $10 \mathrm{~m}$ wide rectangular plots laid out on the

219 lawns perpendicular to the woodland-lawn boundary. The first set of four plots were $12 \mathrm{~m}$ long

220 and were surveyed in July 2014. The second set were $15 \mathrm{~m}$ long and surveyed in March and April

221 2015. These plots are detailed in table S1. The sites for these plots were chosen because they

222 were on sections of the Garden frequently used by all goose species; well separated from each

223 other; were away from other trees and faced different directions. The plots were marked out 
224 using bamboo canes and a tape measure. Then either 20 or 30 randomly chosen $1 \mathrm{~m}^{2}$ square

225 quadrats were surveyed within the rectangular plot. The cumulative length of dropping in a

226 quadrat was measured to the nearest centimetre with a ruler.

227 Analysis of these data was conducted using non-linear mixed effects models using the plot

228 number as a random factor (Crawley, 2012). Calculations were performed using the ' $\mathrm{nlme}$ '

229 package in $\mathrm{R}$ (Pinheiro et al., 2016). Two possible models were compared, a 3-parameter

230 asymptotic exponential model and a 3-parameter logistic sigmoidal function, both with a

231 positive intercept. Model comparisons were made using the Akaike information criterion.

232 Models were conducted using distances perpendicular to the woodland - lawn boundary and

233 for a control modelling was repeated with distances parallel to the woodland - lawn boundary.

\section{Summer goose count data to investigate the influence of islands}

235 Only one of the three lakes in the Botanic Garden has an island and this is the primary nesting

236 site of greylag, Canada and barnacle geese. Nevertheless, with only one island it is impossible to

237 draw conclusions about the importance of islands on habitat choice. Therefore, we used a

238 dataset of summering goose counts from Flanders, that includes the Botanic Garden

239 (Devisscher et al., 2016). These annual counts of geese are collected by volunteers from bird

240 working groups at set sites across Flanders, Belgium. They are conducted simultaneously over

241 one weekend in mid-July, to avoid double counts and when most species have completed their

242 moult but are still found aggregated in larger groups on water bodies (Adriaens et al., 2010,

243 2011). These data are provided with the geographic centroid of the lake. The area of the lake

244 was calculated by tracing it on a GIS system and the area of the lake included the area of any 
245 island in the lake. The presence of an island in the lake was determined from visual inspection

246 of aerial photographs from Google Maps.

\section{Results}

\section{Do geese avoid proximity to trees?}

249 During the study geese were rarely ever observed in woodland. Egyptian geese are occasionally

250 found perched in trees where they nest, but rarely on the ground in woodland. It was

251 hypothesised that this negative association with woodland would extend beyond the boundary

252 between the woodland and lawns and be the cause of an edge effects on grazing.

253 Quantification of the length of geese droppings showed a clear edge effect at the border to

254 woodland (Fig. 2). A shorter length of droppings was found close to the woodland, but this

255 effect only extended 5-10 m from the boundary.

256 As a control modelling was also performed in parallel to the woodland boundary, but models

257 either failed to converge or showed no directional trend.

\section{Which habitat features attract geese?}

259 Here we model the site selection of geese based upon habitat features we suspect might be

260 important to geese. The area of the sector, barriers to flight, presence of woodland and

261 proximity to lakes all appear relevant from observations of geese and the literature cited in the

262 introduction. The mean individual counts of geese in the different sectors of the Garden are

263 mapped in figure 3. From these maps it is clear that all species had a high affinity to the sectors

264 containing lakes, though there are clear differences between species. The greylag geese in 
265 particular are far more wide-ranging than other species notably in the large western sectors.

266 The models of sector usage were evaluated with various means. The Cook's distance was used

267 to evaluate if particular sectors had an exaggerated influence on the model outcomes, but this

268 does not appear to be the case (Fig. S1). Variograms of the residuals did not show evidence for

269 spatial autocorrelation that was not accounted for in the model parameters (Figs S2-S5). A plot

270 of residuals versus fitted values indicates that there may be some non-linearity between the

271 predictors and the abundance of geese, but this was not clear (Fig. S6). The Q-Q plot shows that

272 the residuals were quite normally distributed for all models (Fig. S7). The Scale-Location plot

273 showed that some heteroscedasticity was evident in all models, however we consider that only

274 the model for B. leucopsis was so heteroscedastic that it might impact our interpretation of the

275 results. Given that no real-world model will perfectly match our assumptions and some of the

276 reasons for deviation from these assumptions are suggested in the discussion.

277 A summary of the minimum adequate models is given in table 1 . The simplest minimum

278 adequate model selected was for Anser anser. Only the area of the sector and the presence of

279 woodland were significantly correlated to their distribution in the Garden. Note, that these

280 models do not include areas of the Garden containing a lake. For B. canadensis the area was

281 also positively correlated with the number of geese, but not significantly in the model.

282 However, in contrast to Anser anser, distance from a lake was a significant factor for $B$.

283 canadensis, but also barriers to direct flight and their interacting term. For Alopochen

284 aegyptiaca, area and barriers are significant as single factors, and they reoccur in interacting

285 terms. Distance from the lake was not a significant term, but it did occur in an interaction term

286 with area. In the case of $B$. leucopsis, area was a significant correlate, the other terms are more 
287 difficult to interpret, but both distance from a lake and the presence of barriers remained in the 288 model due to their interactions and their interaction with area.

289 Goose abundance was negatively correlated with woodland for all except B. leucopsis, but this 290 variable is not ideal as all those areas of woodland are also surrounded by trees as barriers to

291 flight, So, there are no areas of woodland without barriers. Therefore, some of the variance 292 stemming from the presence of woodland may be being accounted for in the barrier variable. 293

294 Therefore, for all species the area of the sector was positively correlated with goose abundance 295 and the area was part of the significant interactions included in the models for Alopochen

296 aegyptiaca and Branta leucopsis. The distance from the lake remained in models for all species, 297 except Anser anser. This is also evident in figure 3, where Anser anser can be seen to range 298 more widely than other geese. All other predicted habitat determinants were included in one or 299 more of the models.

300

301 For Canada and greylag geese there was a negative influence of barriers on site usage, 302 particularly for Canada geese. In the case of Egyptian and barnacle geese, barriers were not a 303 clear determinant of site selection, but did remain in minimum adequate models as interactions 304 with distance and area.

\section{Do islands in lakes attract geese?}

306 Lakes with islands attract more Canada, greylag and barnacle geese in the summer (Fig. 4).

307 These results indicate that a lake without an island had 35\%-60\% fewer anserine geese than a 
308 lake of an equivalent size with an island $(p<.05)$. However, islands made no difference to the

309 number of Egyptian geese. All goose numbers showed a positive relationship with lake size

$310(p<0.05)$, although this is not significant in the case of barnacle geese.

\section{Discussion}

312 The modelling results, edge effects and impact of islands demonstrated the complicated

313 relationship between habitat choice and the landscape for suburban geese (Fig. 1, Fig. 2, Table

314 1). A casual observer could assume that there is a rather passive relationship between geese

315 and their landscape, but as with any other animal, geese are clearly actively selecting and using

316 particular landscapes and landscape features suited to their preferences.

317 Edge effects are relevant to the usage of geese on lawns because they reduce the active area of

318 use for the geese. Our methodology did not distinguish whether there are species differences,

319 however, the effect was so distinct that we speculate that all species are influenced. While

320 there may be many potential causes of an edge effect, such as predator avoidance and poorer

321 grazing, an area of lawn less than $20 \mathrm{~m}$ in diameter is likely to be undesirable to geese.

322 However, with increasing ratio of area to circumference means that the relevance of this effect

323 will diminish with increasing area. In ornamental parks individual specimen trees might extend

324 the influence of this edge effect.

325

326 Sector area was the most consistent predictor of goose abundance (Table 1). This was

327 anticipated, as more space can contain more geese. Yet in addition to the edge effects there

328 are reasons to expect a more sophisticated relationship between goose number and area. 
329 Firstly, anserine geese are social species forming large flocks and they may only select areas

330 with sufficient capacity to hold the whole flock. Secondly, if an area is surrounded by tall trees

331 the flight angle needed to enter and leave it from the air becomes progressively steeper the

332 smaller the area becomes. Mature trees stand $15-20 \mathrm{~m}$ tall, but average vertical and horizontal

333 airspeeds of geese are approximately $0.5 \mathrm{~m} \mathrm{~s}^{-1}$ and $16 \mathrm{~m} \mathrm{~s}^{-1}$ respectively (Hedenström \&

334 Alerstam, 1992). Therefore, to enter and escape a small area surrounded by trees they must

335 either considerably steepen their descent or climb rate, or circle while gaining or losing height.

336 Both of these strategies would be more energetically expensive (Norberg 1996). For these

337 reasons, it is not surprising that the area of the sector also appears in interacting terms in the

338 models with barriers. Barriers particularly restrict movement of geese when flight is not an

339 option, such as, when raising young or moulting. However, the negative influence of barriers

340 was scarcely significant for Alopochen aegyptiaca. This may be a result of their behaviour of

341 nesting in tree holes. Though they do not inhabit densely forested areas, their preferred habitat

342 is open grassland with some trees in proximity to freshwater (Cramp et al., 1984; Carboneras,

343 1992; Gyimesi and Lensink, 2012). They defend territories around nest sites and therefore must

344 be in proximity to trees (Sutherland \& Allport, 1991).

345

346 Distance from lakes was not as important to site selection as had been assumed, and the

347 interactions with area and the presence of barriers suggests that the ease of access to grazing is

348 more important to site selection than the linear distance. This perhaps indicates that careful

349 usage of landscape features could guide geese to use particular feeding sites, irrespective of

350 their distance from the lake.

Peer] reviewing PDF | (2020:01:45121:2:0:NEW 21 Jul 2020) 
351

352 The results show a strong preference of anserine geese for lakes with islands during the

353 summer (Fig. 4). Islands are used by geese year-round, as they provide protection from

354 disturbance where geese can rest and nest. The lack of a similar preference for Egyptian geese

355 is consistent with the territorial breeding behaviour of Egyptian geese and their use of nest

356 holes in trees. Although anserine geese prefer lakes with islands in the summer, the reasons are

357 probably many and this preference may not be true in winter. Island breeders are presumably

358 more protected from predators, particularly foxes (Vulpes vulpes) (Wright \& Giles, 1988), stone

359 marten (Martes foina), brown rat (Rattus norvegicus) and carrion crow (Corvus corone)

360 (Huysentruyt et al. 2020). However, when breeding success on islands has been examined it is

361 not always better than on the mainland (Gosser \& Conover, 1999; Petersen, 1990). Other

362 studies on the influence of islands on goose nest site selection vary. Fox et al. (1989) showed

363 no influence for greylag goose, whereas others report an effect for Canada Goose (Lokemoen \&

364 Woodward, 1992; Bromley \& Hood, 2013). Huysentruyt et al. (2020), in their study of 200

365 breeding pairs of barnacle goose in Flanders, also note that barnacle goose mainly breeds on

366 small islands in lakes and ponds in the region.

367

368 Based on the results of this study we suggest that landscape adaptations could indeed reduce

369 the number of geese in suburban parks, which could be an alternative to lethal control and

370 prevent conflict with people. Unfortunately, many of the landscape adaptations that would

371 reduce the presence of geese are in opposition to popular landscape design features, such as

372 ponds and lakes, islands, open vistas and extensive lawns. Other sorts of landscape and garden 
373 design with more enclosed and higher vegetation are more suitable where geese are a

374 problem. Woodlands, shrubberies, coppice, hedges, tall grass meadows, prairie planting, hard

375 landscaping features, shallow water and moving-water features would all deter geese from

376 using an area (Allan, Kirby \& Feare, 1995; Gosser, Conover \& Messmer, 1997; Allan, 1999;

377 Baxter, Hart \& Hutton, 2010).

378

379 If artificial islands were eliminated from suburban lakes it might be argued that native birds

380 would also suffer from the lack of island breeding sites, however, islands in suburban parks are

381 mostly unsuitable for island nesters of conservation concern, such as common terns (Sterna

382 hirundo) which do breed well on artificial rafts in bigger lakes and lagoons (Coccon et al., 2018;

383 Dunlop et al., 1991). Islands could perhaps be made less attractive if they were connected to

384 the mainland by constructing bridges or an isthmus. They can also be modified with banks that

385 deter access from the water, rather than from the air. However, making feeding areas

386 inaccessible is controversial as chicks can then starve (Allan 1999). Modifications or removal of

387 islands should however consider the trade-off with ongoing management. For example, when

388 practicing egg shaking or egg oiling for fertility reduction, the success of this measure depends

389 on sustained effort and a high percentage of treated nests (Klok et al., 2010; Beston et al.,

390 2016). Hence, having all geese nest on the same island makes it easier to perform this

391 management.

392

393 There is also a need to educate the public to the benefits of geese. In the Botanic Garden their

394 selective grazing of grasses has created an exceptional species rich grassland that is unlikely to 
395 be maintained with mowing alone (Ronse 2011). An adaptive management approach, whereby

396 vegetation and goose numbers in the Garden are thoroughly monitored and objectives are

397 clearly stipulated, could be a good way to learn more about the behaviour and impacts of

398 geese.

\section{Conclusions}

400 Landscape features have a powerful influence on the distribution of geese, though these

401 influences differ between species. For example, we show that...

402 - Lakes with islands attract more than twice as many anserine geese

403 - Flight barriers between grazing areas and lakes deter geese

404

- Small grazing areas surrounded by trees reduces their attractiveness to geese

405

- Proximity of a lake is most important to Canada geese, and least to greylag geese

Landscape modifications cannot completely remove geese from a suburban landscape and an

407 integrated management strategy may be necessary (Allan, Kirby \& Feare, 1995). Retroactively

408 modifying landscapes to reduce their attractiveness to geese is difficult, so designing

409 landscapes for wildlife usage should be among the primary design criteria.

\section{Acknowledgements}

411 The authors would like to thank Didier Vangeluwe of the Royal Belgian Institute of Natural

412 Sciences and Danny Swaerts of the Meise Botanic Garden for their support and advice during

413 the project. 


\section{Literature Cited}

415 Adriaens T, Close A, Robertson P, Maillard J-F, Guillemain M, Pernollet CA, Huysentruyt F.

416 2019. Canada Goose (Branta canadensis Linnaeus, 1758). In: Downs CT \& Hart LA. (eds)

417 Global Trends and Impacts of Alien Invasive Birds. CAB International, Wallingford, UK.

418 Adriaens T, Huysentruyt F, Devisscher S, Devos K, Casaer J. 2010. Simultaantelling

419 overzomerende ganzen in Oost- en West- Vlaanderen. Vogelnieuws 15: 4-11.

$420 \quad$ https://pureportal.inbo.be/portal/files/275117/228715.pdf

421 Adriaens T, Huysentruyt F, Devisscher S, Devos K, Casaer J. 2011. Simultaantelling

422 overzomerende ganzen in Oost- en West- Vlaanderen. Vogelnieuws 17: 24-30.

423 https://pureportal.inbo.be/portal/files/275113/228713.pdf

424 Allan JR. 1999. The management of problems caused by Canada geese: a guide to best 425 practice. Department of the Environment, Transport and the Regions.

426 Allan JR, Kirby JS \& Feare CJ. 1995. The biology of Canada geese Branta canadensis in

427 relation to the management of feral populations. Wildlife Biology, 1(1), 129-143.

428 Anselin A \& Cooleman S. 2007. Wintertelling van de Canadese Gans, Branta canadensis in

429 Vlaanderen (2007). Rapport van het Instituut voor Natuur-en Bosonderzoek. INBO.R.2007.9.

43016 pp. Part of: Rapport van het Instituut voor Natuur- en Bosonderzoek. Instituut voor

$431 \quad$ Natuur- en Bosonderzoek: Brussel. ISSN 1782-9054.

432 Austin GE, Rehfisch MM, Allan JR \& Holloway SJ. 2007. Population size and differential 433 population growth of introduced Greater Canada Geese Branta canadensis and re- 
434 established Greylag Geese Anser anser across habitats in Great Britain in the year 2000. Bird 435 Study 54:343-352 DOI: 10.1080/00063650709461494

436 Baxter A, Hart J \& Hutton S. 2010. A Review of Management Options for Resolving Conflicts 437 with Urban Geese. Bird management unit, Food and Environment Research Agency, UK 438 Government.

439 Beston JA, Williams CK, Nichols TC, Castelli PM. 2016. A population model for management 440 of Atlantic flyway resident population Canada geese. Wildlife Society Bulletin, 40, 106-111.

441 Bönner BM, Lutz W, Jäger S, Redmann T, Reinhardt B, Reichel U, Krajewski V. Weiss R, 442 Wissing J, Knickmeier W, Gerlich WH, Wend UC \& Kaleta EF. 2004. Do Canada geese (Branta 443 canadensis Linnaeus, 1758) carry infectious agents for birds and man? European Journal of $444 \quad$ Wildlife Research 50:78-84 DOI: 10.1007/s10344-004-0044-1

445 Bromley CK, Hood GA. 2013. Beavers (Castor canadensis) facilitate early access by Canada 446 geese (Branta canadensis) to nesting habitat and areas of open water in Canada's boreal 447 wetlands. Mammalian Biology 78(1):73-7.

448 Buij R, Melman ThCP, Loonen MJJE, Fox AD. 2017. Balancing ecosystem function, services 449 and disservices resulting from expanding goose populations. Ambio 46 (Suppl 2): 301-331. 450 DOI: $10.1007 /$ s13280-017-0902-1

451 Clark L. 2003. A review of pathogens of agricultural and human health interest found in 452 Canada Geese. USDA National Wildlife Research Center-Staff Publications, 205.

453 Coccon F, Borella S, Simeoni N, Malavasi S. 2018. Floating rafts as breeding habitats for the 
454 Common tern, Sterna hirundo. Colonization patterns, abundance and reproductive success

455 in Venice Lagoon. Rivista Italiana di Ornitologia 88(1): 23-32.

456 Conover MR. 1985. Alleviating nuisance Canada goose problems through methiocarb-

457 induced aversive conditioning. The Journal of Wildlife Management 49:631-636

458 Conover MR 1991. Herbivory by Canada geese: diet selection and effect on lawns. Ecological 459 Applications 1:231-236. DOI: 10.2307/1941816

460 Conover MR, Chasko GG. 1985. Nuisance Canada goose problems in the eastern United 461 States. Wildlife Society Bulletin 13:228-233.

Conover MR, Kania GS. 1991. Characteristics of feeding sites used by urban-suburban flocks 463 of Canada geese in Connecticut. Wildlife Society Bulletin 19:36-38 Conover MR. 1992. Ecological Approach to managing problems caused problems caused by urban Canada geese. Proceedings of the Fifteenth Vertebrate Pest Conference 1992. Paper 19. http://digitalcommons.unl.edu/vpc15/19

Cooper JA. 1998. The potential for managing urban Canada geese by modifying habitat.

468 Proceedings of the Vertebrate Pest Conference, 18. DOI: 10.5070/V418110168

$471 \quad$ Barcelona, pp.536-629.

472 Cramp S, Simmons KEL, Ferguson-Lees IJ, Gillmor R, Hollom PAD, Hudson R, Nicholson EM, 
473 Ogilvie MA, Olney PJS, Voous KH, Wattel J. 1984. Handbook of the birds of Europe, the

474 Middle East, and North Africa: the birds of the Western Palearctic. Vol. 1 Ostrich to Ducks.

475 Oxford University Press, Oxford.

476 Crawley MJ. 2012. The R book. John Wiley \& Sons. Chichester, UK.

477 Devisscher S, Adriaens T, Brosens D, Huysentruyt F, Driessens G, Desmet P. 2016.

478 Zomerganzen - Summering geese management and population counts in Flanders, Belgium.

479 v1.1. Research Institute for Nature and Forest (INBO). Dataset/Samplingevent. DOI:

$480 \quad 10.15468 / a 5 u b t p$

481 Dunlop CL, Blokpoel H, Jarvie S. 1991. Nesting rafts as a management tool for a declining

482 common tern (Sterna hirundo) colony. Colonial Waterbirds 14(2): 116-120.

483 Feige N, van der Jeugd HP, van der Graaf AJ, Larsson K, Leito A, Stahl J. 2008. Newly

484 established breeding sites of the Barnacle Goose Branta leucopsis in North-western Europe

$485-$ an overview of breeding habitats and colony development. Vogelwelt 129:244-252.

486 Fleming R, Fraser H. 2001. The impact of waterfowl on water quality - literature review.

487 University of Guelph, Ridgetown, Ontario, Canada.

488 Fox $A D$, Kahlert J. 2005. Changes in body mass and organ size during wing moult in non

489 breeding greylag geese Anser anser. Journal of Avian Biology 36:538-548 DOI

$490 \quad \underline{10.1111 / j .0908-8857.2005 .03301 . x}$

491

492

Fox AD, Ebbinge BS, Mitchell C, Heinicke T, Aarvak T, Colhoun K, Clausen P, Dereliv S, Farago

S, Koffijberg K, Kruckenberg H, Loonen MJJE, Madsen J, Mooij J, Musil P, Nilsson L, Pihl S, 
493 van der Jeugd H .2010. Current estimates of goose population sizes in western Europe, a 494 gap analysis and an assessment of trends. Ornis Svecica 20: 115-127.

495 Fox AD. 2019. Urban Geese-looking to North America for experiences to guide 496 management in Europe?. Wildfowl, 69(69), 3-27.

497 Gosser A, Conover M. 1999. Will the Availability of Insular Nesting Sites Limit Reproduction 498 in Urban Canada Goose Populations? The Journal of Wildlife Management 63: 369-373.

499 Gosser AL, Conover MR, Messmer TA. 1997. Managing problems caused by urban Canada $500 \quad$ geese. All Archived Publications. Paper 1023.

501 http://digitalcommons.usu.edu/extension_histall/1023

502 Groom Q. 2019a. A map describing routes used in goose monitoring at Meise Botanic 503 Garden. Zenodo. DOI: 10.5281/zenodo.2529725

504 Groom Q. 2019b. Goose monitoring data from the Meise Botanic Garden, Belgium [Data 505 set]. Zenodo. DOI: $\underline{10.5281 / \text { zenodo.2529723 }}$

506 Groom Q. 2019c. Waterbirds of the Botanic Garden Meise. Version 3.6. Botanic Garden 507 Meise. Occurrence dataset DOI: 10.15468/cgffyq accessed via GBIF.org on 2019-01-05.

508 Gyimesi A, Lensink R. 2010. Risk analysis of the Egyptian goose in the Netherlands. report $509 \quad$ \#09-617. Culemborg: Bureau Waardenburg.

510 Gyimesi A, Lensink R. 2012. Egyptian Goose Alopochen aegyptiaca: an introduced species 511 spreading in and from the Netherlands. Wildfowl 62:128-145. 
512 Haahr M. 2019. RANDOM.ORG: True Random Number Service. Retrieved from

513 https://www.random.org

514 Hassall M, Riddington R, Helden A. 2001. Foraging behaviour of brent geese, Branta $b$.

515 bernicla, on grasslands: effects of sward length and nitrogen content. Oecologia 127:97-

516 104. DOI: $10.1007 / \mathrm{s} 004420000563$

517 Hedenström A, Alerstam T. 1992 Climbing performance of migrating birds as a basis for

518 estimating limits for fuel-carrying capacity and muscle work. Journal of Experimental Biology

$519 \quad 164(1): 19-38$.

520 Hughes B, Kirby J, Rowcliffe JM. 1999. Waterbird conflicts in Britain and Ireland: ruddy ducks

521 Oxyura jamaicensis, Canada geese Branta canadensis, and cormorants Phalacrocorax carbo.

522 Wildfowl 50:77-99.

523 Huysentruyt F, Casaer J. 2010. Het bepalen van mogelijke herkomstgebieden bij

524 landbouwschade door overzomerende ganzen : Een eerste aanzet voor een modelmatige

525 benadering. Rapporten van het Instituut voor Natuur- en Bosonderzoek INBO.R.2010.9.

$526 \quad$ Instituut voor Natuur- en Bosonderzoek, Brussel.

527 Huysentruyt F, Verschelde P, Van Daele T, Casaer J, Neukermans A, Adriaens T. 2020.

528 Management options for a resident Barnacle Goose (Branta leucopsis) population in

529 Flanders. Reports of the Research Institute for Nature and Forest 2020 (1). Research

$530 \quad$ Institute for Nature and Forest, Brussels. DOI: 10.21436/inbor.17611440

531 Huysentruyt F, Callaghan CT, Strubbe D, Winston K, Adriaens T, Brooks DM. 2019. 14 
532 Egyptian Goose (Alopochen aegyptiaca Linnaeus, 1766). In Downs CT \& Hart LA. (eds),

533 Global trends and impacts of alien invasive birds. CABI, Wallingford, UK.

534 Kéry M, Schmidt B. 2008. Imperfect detection and its consequences for monitoring for 535 conservation. Community Ecology 9:207-216 DOI: 10.1556/ComEc.9.2008.2.10

536 Klok C, Van Turnhout C, Willems F, Voslamber B, Ebbinge B, Schekkerman H. 2010. Analysis

537 of population development and effectiveness of management in resident greylag geese

538 Anser anser in the Netherlands. Animal Biology, 60, 373-393.

539 Livezey BC. 1996. A phylogenetic analysis of geese and swans (Anseriformes: Anserinae),

$540 \quad$ including selected fossil species. Systematic Biology 45(4):415-450.

541 Lokemoen JT, Woodward RO. 1992. Nesting waterfowl and water birds on natural islands in

542 the Dakotas and Montana. Wildlife Society Bulletin 20(2):163-171.

543 Miller CA, Campbell LK, Yeagle JA \& Colligan CB. 2001. Attitudes of Homeowners in the

544 Greater Chicago Metropolitan Region Toward Nuisance Wildlife. Human Dimensions

545 Program Report SR-00-02. Illinois Natural History Survey, Champaign, IL.

546 Norberg UM. 1996. Energetics of Flight. In: Carey C. (eds) Avian Energetics and Nutritional

547 Ecology. Springer, Boston, MA

548 Olsson C, Gunnarsson G, Elmberg. 2017. Field preference of Greylag geese Anser anser

549 during the breeding season. European Journal of Wildlife Research 63:28 DOI:

$550 \quad 10.1007 /$ s10344-017-1086-5 
551 Owen M. 1971. The Selection of Feeding Site by White-Fronted Geese in Winter. Journal of $552 \quad$ Applied Ecology 8:905-917 DOI: $10.2307 / 2402690$

553 Owen M. 1975. Cutting and fertilizing grass land for winter goose management. The Journal 554 of Wildlife Management 39:163-167.

555 Owen M, Nugent M, Davies N. 1977. Discrimination between grass species and nitrogen556 fertilized vegetation by young barnacle geese. Wildfowl 28:21-26

557 Petersen MR. 1990. Nest-site selection by emperor geese and cackling Canada geese. The $558 \quad$ Wilson Bulletin 102(3):413-426

559 Pinheiro J, Bates D, DebRoy S, Sarkar D, R Core Team. 2016. nlme: Linear and Nonlinear $560 \quad$ Mixed Effects Models. R package version 3.1-124, http://CRAN.R-

561 project.org/package=nlme.

562 Reyns N, Casaer J, De Smet L, Devos K, Huysentruyt F, Robertson PA, Verbeke T, Adriaens T.

563 2018. Cost-benefit analysis for invasive species control: the case of greater Canada goose

564 Branta canadensis in Flanders (northern Belgium). PeerJ 6:e4283. DOI: 10.7717/peerj.4283

565 Ronse A. 2011. The wild flora of the Botanic Garden: an introduction. The spontaneous flora 566 of the National Botanic Garden of Belgium (Domein van Bouchout, Meise). Scripta Botanica 567 Belgica 47:27-58. Si Y, Skidmore AK, Wang T, de Boer WF, Toxopeus AG, Schlerf M, Oudshoorn M, Zwerver S, 569 van der Jeugd H, Exo KM, Prins HH. 2011. Distribution of Barnacle Geese Branta leucopsis in 570 relation to food resources, distance to roosts, and the location of refuges. Ardea 99(2): 217- 
571226.

572 Smith AE, Craven SR, Curtis PD. 1999. Managing Canada geese in urban environments. Jack

573 Berryman Institute and Cornell University Cooperative Extension Publication 16, Ithaca,

$574 \quad$ New York, USA.

575 Sutherland WJ, Allport G. 1991. The distribution and ecology of naturalized Egyptian Geese $576 \quad$ Alopochen aegyptiacus in Britain. Bird Study 38:128-134.

577 Turner R. 1985. Capability Brown and the eighteenth century English landscape. Rizzoli.

578 Van der Wal R, Kunst P, Drent R. 1998. Interactions between hare and brent goose in a salt 579 marsh system; evidence for food competition?. Oecologia. 117(1-2):227-234.

580 Van Daele P, Adriaens T, Devisscher S, Huysentruyt F, Voslamber B, De Boer V, Devos K,

581 Casaer J. 2012. Beheer van zomerganzen in Vlaanderen en Zeeuws-Vlaanderen. Rapporten 582 van het Instituut voor Natuur- en Bosonderzoek INBO.R.2012.58, Brussels, Belgium. 162 pp.

583 Van Gils B, Huysentruyt F, Casaer J, Devos K, De Vliegher A, Carlier L. 2009. Project

584 Winterganzen 2008-2009: onderzoek naar objectieve schadebepaling. Rapport van het 585 Instituut voor Natuur- en Bosonderzoek INBO.R.2009.56. Instituut voor Natuur- en

$586 \quad$ Bosonderzoek, Brussel.

587 Venables WN, Ripley BD. 2002. Modern Applied Statistics with S. New York: Springer (4th 588 ed). 
590 and Anser anser on gravel pits. Bird Study 35(1):31-35. 


\section{Figure 1}

A map of the surveyed areas of the Garden

Maps of the Botanic Garden Meise where yellow indicates (A) the areas of woodland and (B) those areas largely surrounded by tall trees that act as barriers to direct flight of the geese out of that area. Light blue areas are lakes and pink areas were not surveyed. The unsurveyed areas are either covered by woodland, buildings or greenhouses. The axis are the UTM coordinates, zone $31 \mathrm{U}$.

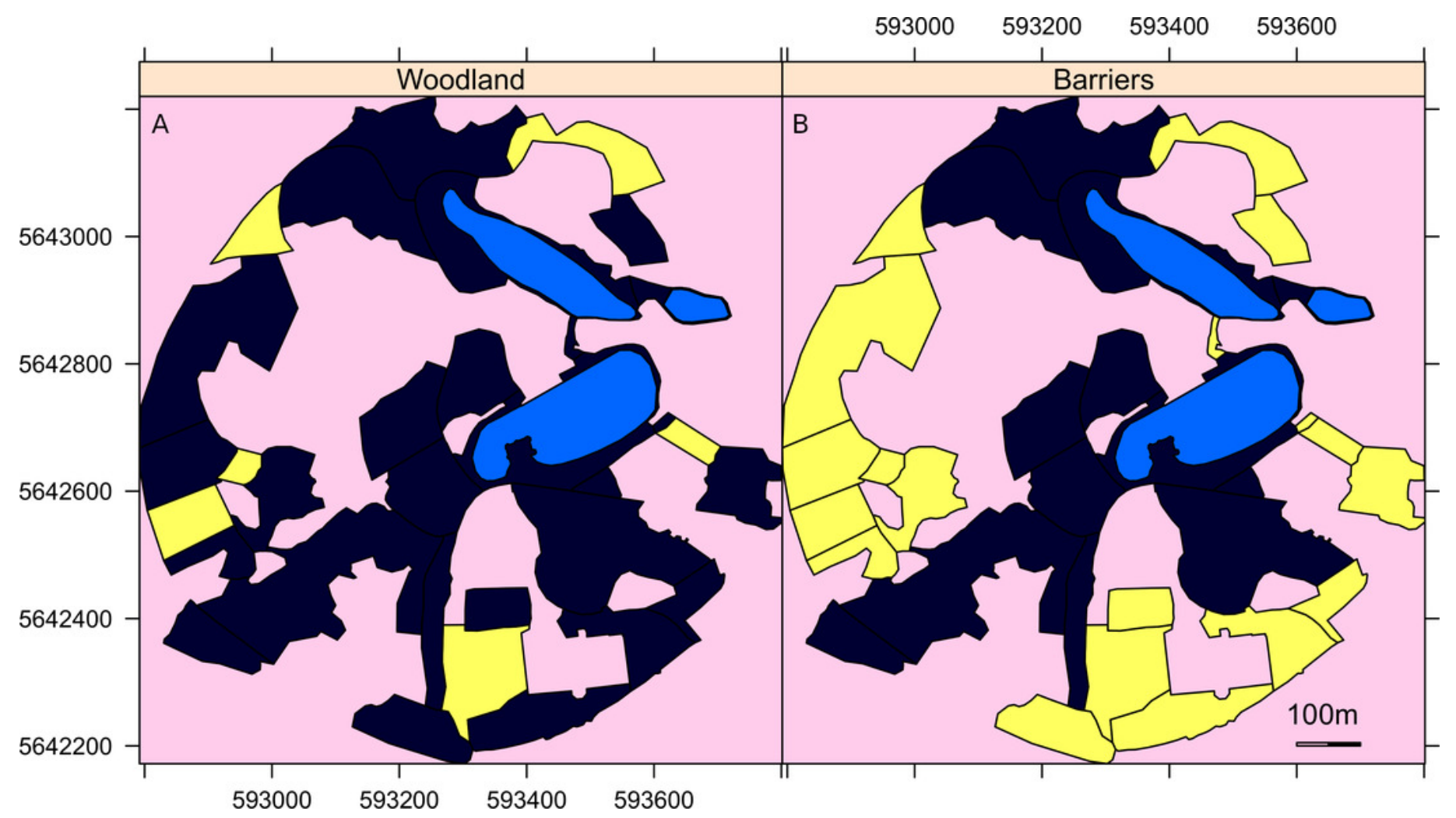




\section{Figure 2}

Geese land usage measure by the droppings deposited at varying distances from the boundary between woodland and lawn.

The total length of geese droppings deposited at varying distances from the boundary between woodland and lawn. Geese dropping were the sum length of all dropping from all species of geese. The numbers on each graph refer to the original plot number. See the methods for details of the model applied to the data. 


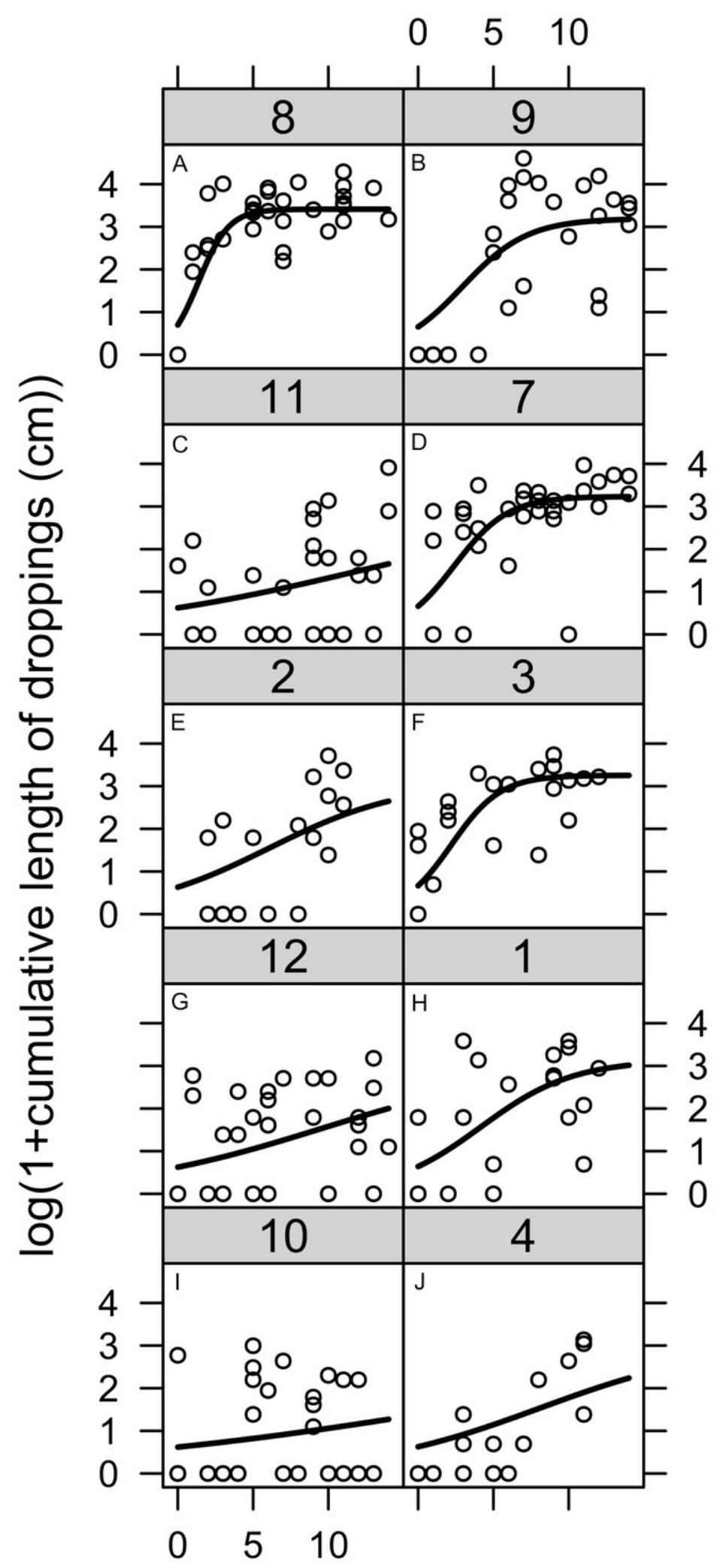

\section{Distance from trees $(\mathrm{m})$}




\section{Figure 3}

Maps of the area of the Garden use by the different species of geese.

Maps of the mean number of individuals of (A) Alopochen aegyptiaca, (B) Anser anser, (C) Brata canadensis and (D) B. leucopsis in the surveyed areas of the Botanic Garden. Lakes are in light blue, unsurveyed areas are in pink. The axis are the UTM coordinates, zone 31U.

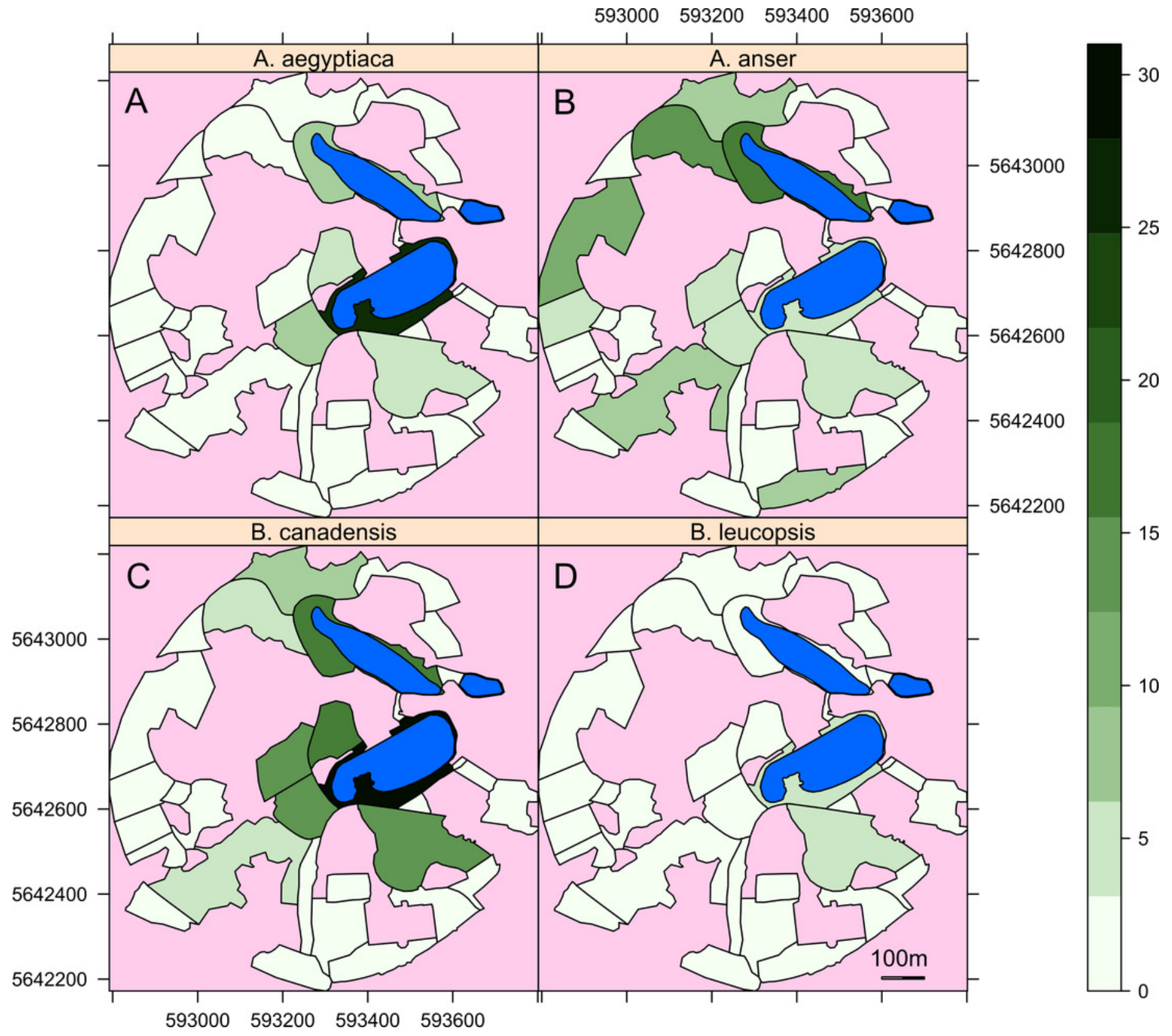




\section{Figure 4}

A comparison of the numbers of geese found at lakes with or without islands.

A comparison of summer goose counts for lakes in Flanders compared to the lake area, either with islands (dashed line) or without islands (solid line). The lines are the results of linear models of the log of the average individual count on a lake and the log of the area of the lake. The models assume a constant relationship between average individual count of geese and the lake's area (A) Branta canadensis $\left(\mathrm{R}^{2}=.16, \mathrm{~F}(2,119)=10.98, \mathrm{p}<.001\right)$ (B) Anser anser $\left(R^{2}=.12, F(2,118)=8.16, p<.001\right)$ (C) Branta leucopsis $\left(R^{2}=.09, F(2,118)=6.16, p<.01\right)$ (D) Alopochen aegyptiaca $\left(R^{2}=.10, F(2,118)=6.77, p<.01\right)$. There is a significantly larger number of Canada $(t=3.79, p<.001)$, greylag $(t=2.22, p<.05)$ and barnacle geese $(t=3.42$, $p<.001)$ on lakes with islands. There is a significant positive relationship between the lake area and counts of Canada $(t=2.58, p<.05)$, greylag $(t=3.30, p<.001)$ and Egyptian geese $(t=3.58, p<.001)$. 
Branta canadensis

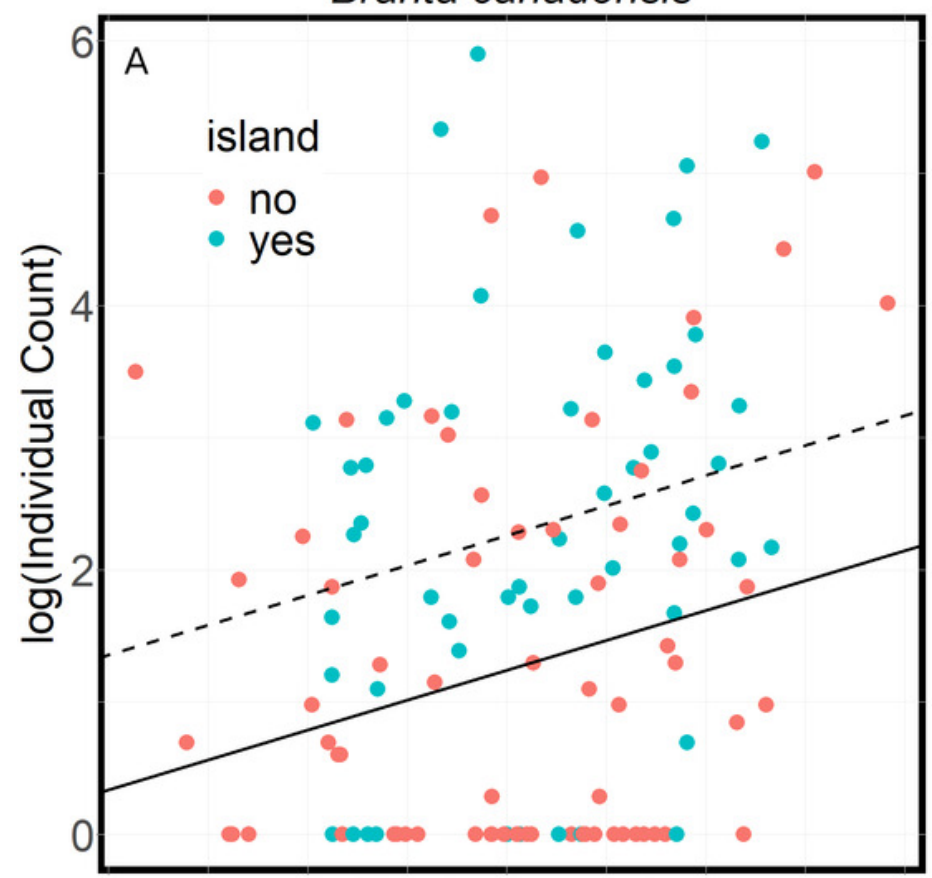

Branta leucopsis

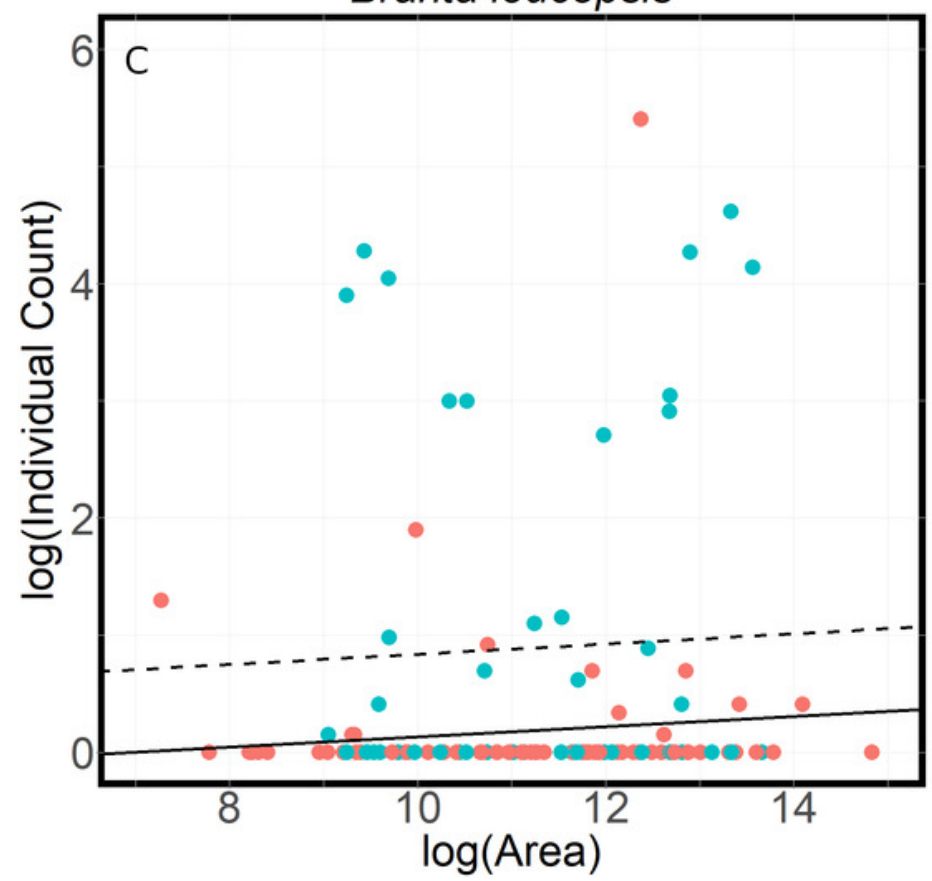

Anser anser B

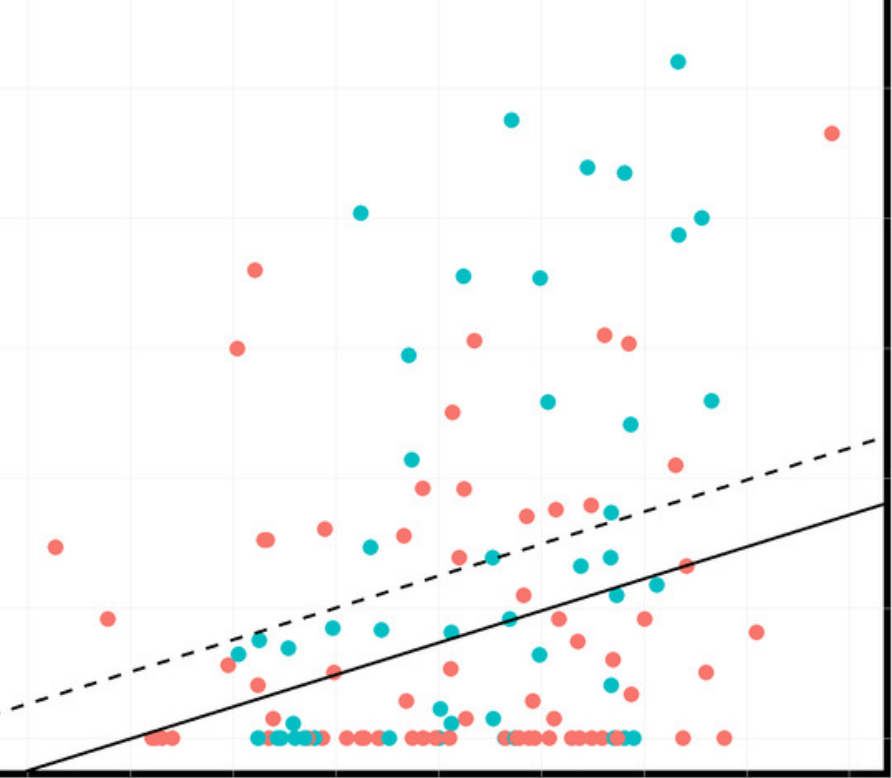

Alopochen aegyptiaca

D

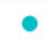

-
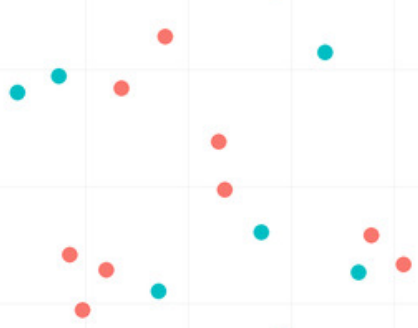

-

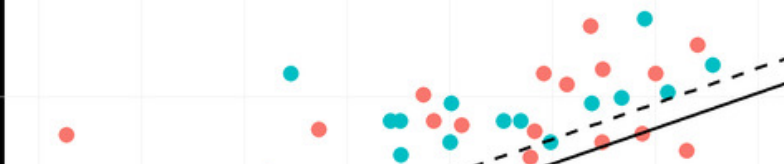




\section{Table $\mathbf{1}$ (on next page)}

A summary of the minimum adequate models results for the distribution of geese in the Garden

+ indicate a positive association of geese numbers with the independent variables and - a negative association. The independent variables are the area of that sector of the garden, the distance from a lake, the presence of woodland on the garden sector and barriers to direct flight out of a sector. The number of asterisks indicate the degree of significance $(* p<$ $0.05 ; * * p<0.01 ; * * * p<0.001$ ). Details of the models are presented in tables S2, S3, S4 and S5. 


\begin{tabular}{|c|c|c|c|c|}
\hline & $\begin{array}{l}\text { Alopochen } \\
\text { aegyptiaca }\end{array}$ & Anser anser & $\begin{array}{l}\text { Branta } \\
\text { canadensis }\end{array}$ & $\begin{array}{l}\text { Branta } \\
\text { leucopsis }\end{array}$ \\
\hline area & $+*$ & $+* * *$ & + & $+* *$ \\
\hline distance from a lake & + & & $-* * *$ & + \\
\hline Woodland & - & _** & - & \\
\hline Barriers to direct flight & -* & & - $* * *$ & + \\
\hline area:distance & _* & & & _* \\
\hline area:barriers & $+*$ & & & - \\
\hline distance:barriers & & & $+* * *$ & - \\
\hline area:distance:barriers & & & & $+*$ \\
\hline
\end{tabular}

